\title{
Medical House blues
}

\section{Ronald Ruskin}

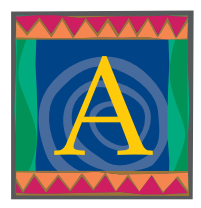

t Homecoming a flock of Old Boys returned to Medical House. They inspected the worn bricks and windows, ran fingers over rusted railings and faded wooden banisters, stared at black-and-white photos of lost Old Boys on walls. They walked around the house. They sniffed the scent of wood-rot. They shook their heads and whispered.

Who was caring for this house?

It was falling apart. One day, in the not-too-distant future, Medical House would disappear. The Old Boys feared finding its remains in an empty lot of weeds.

The way I heard it, Medical House had been disintegrating since it was built. Each year it disintegrated faster than the year before, and so the Old Boys worried that it was approaching a final landslide. First it was the roof, then the third-floor windows and then the basement pipes. The TV lost its picture and made hissing noises. The living room piano whimpered and played flat. The chimney housed a squirrel family, and raccoons and mice scurried in the attic. At night no one slept.

We tried traps, exterminators and cats; the rodents outwitted us. The toilets were often unusable, the floors buckled and sagged, the walls leaned and veered, and the old gas stove sometimes shot blue flames to the ceiling so that you never knew if your food would be undercooked, charred or instantly vaporized.

Old Boys came to drop off cheques and offer homilies on Life and Medicine. Once a year a retired surgeon named Reginald Boots would hand over $\$ 500$, down several Scotches, give a rambling and maudlin speech about how Medical House saved his life, and drive erratically away in his black Cadillac. He never ended his story. I figured he'd cheated on exams, embezzled medical funds, botched operations or killed a few patients. Guilt was written over his bleary, contrite face.

I wondered if fate hung over Medical House, like in some Greek tragedy.

We were the New Boys, a motley bunch of student yokels. We arrived from across Canada, miserable, nihilistic and lost. If anything, Medical House was a place to converge in our despair. Some of us roomed at Medical House; most lived in flats and paid board. Meals were cheap, no one died of food poisoning, beer cost a quarter. On weekends we washed, cleaned, sanded, scraped and painted the old walls and wooden doors. We swept the basement, stoked coal-bins and raked the yard. We shovelled snow in winter and picked up leaves in the fall.

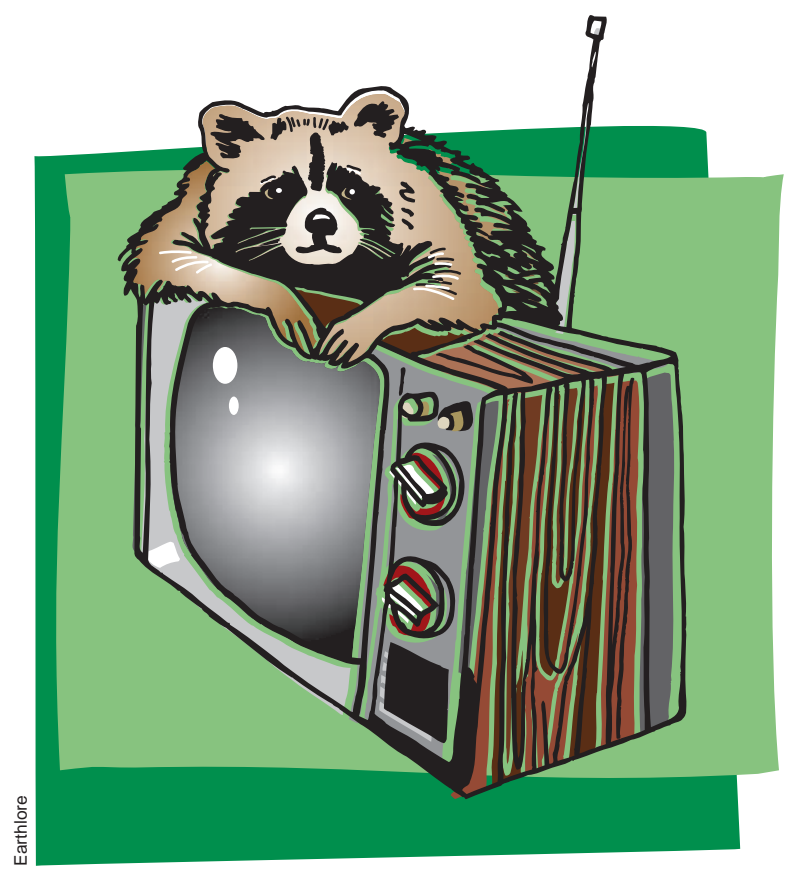

I considered myself an artist and drew a still-life for the hall.

"Amazing," said Frank, my anatomy partner. "You are another Cézanne."

Frank fixed the television. He took out all the tubes and wires and small pieces, cleaned them off, and put them back. It was like new.

Better than new, actually. It had new powers.

"I wanted to do electrical engineering instead of medicine," Frank said.

"You are Edison," I said. "I am Cézanne."

The two of us were undiscovered geniuses.

Everyone handed Frank their broken toasters, radios and stereos.

To tell you the truth, we hardly watched TV except for Hockey Night in Canada. After Frank fixed the TV, the picture returned and we heard Foster Hewitt's voice on the old set for the first time. The only thing was that the TV gave off an odd smell. We thought nothing of it. Then the TV started to sizzle, although the picture and sound were exceptional. We took to wearing gloves when we turned it on because it growled and vibrated and gave nasty shocks.

One evening a student reported purple sparks flying out of the TV. A new sound-and-light effect.

Frank took it apart again, cleaned all the tubes, put in new wires and stuck everything together with surgical tape and bandages he'd pilfered from Emergency. It worked fine 
after that, except the programs came from Quebec and everyone spoke French.

The next day the TV caught fire and blew itself up.

At Medical House, you stuffed yourself and went back for seconds or thirds. Some days though, after anatomy, my appetite deserted me and did not return until late evening, when I made triple-decker turkey sandwiches with tomatoes, lettuce, cheese, mustard and pickles. Medical House had an honour system. On the kitchen fridge was a warning:

Eating is fine as long as you pay for it.

Criminals caught eating will be shot.

Those shot will be cooked or pickled.

It was impossible to collect from medical students. All of us lived below the poverty line. No one had a head for practical matters, business or saving money. We had a talent for accumulating enormous debts. So did Medical House. By month-end I had existential blues: my expenses, books, rent, food, failed art, exam-anxiety, lovesickness and homesickness made me wretched. I put my paintings in local shows; none of them sold. I was never going to be famous. I wasn't even going to be able to pay the next month's rent.

After dinner I slumped in the living room, forlorn.

My buddy Todd played piano at Medical House. We listened to his blues. Todd had enough blues to go around for everyone. He always started with Lullaby of Birdland.

"Why do you begin that way?" Frank asked.

"How do you mean?" Todd played on, hitting a few mournful chords.

"You always start off with Lullaby."

Todd replied. "The blue notes groove me."

I felt that groove. Listening to his music put you in that place. But the piano was not right. Some demented medical student had shoved thumbtacks in the hammers and the piano sounded honky-tonk. Todd brought a toolbox and opened the ancient Heintzman. He lifted the cover, removed the front and extracted thumbtacks with surgical forceps.

"Idiots. Cretins." Todd pulled the tacks and dropped them into a metal tray. He took out a tuning fork, a felt strip and wrenches.

"What are you doing?" I asked.

"In my other life," Todd said, "I was a piano tuner."

Todd tuned each string, treble to bass, adjusted the pedals and cleaned the piano. Inside were scraps of sheet music, dried fruit, old toast and a yellowed condom. Todd re- placed the cover and polished the wood with lemon oil. He cleaned the keys with vinegary water until the film of dirt disappeared. The keys gleamed ebony and ivory. Todd sat down and played Lullaby again.

The piano was eerily lush, the notes echoed, the diminished minor chords stayed inside of you. The sound glowed, shading everything lighter, softer in your mind. Todd was 31, eight years older than me. Frank and I thought he was brilliant, another Oscar Peterson.

"Who wrote Lullaby?" Frank asked.

"George Shearing, I think."

We were all so brilliant and painfully sensitive.

Todd wanted to be a jazz pianist. Frank wanted to be Thomas Alva Edison, yet his electrical experiments failed tragically. By the end of first year I started to doubt ever becoming Cézanne. All my paintings remained unsold. Still, we clung together - the three melancholic musketeers, Edison, Cézanne, Peterson.

Twenty-five years after graduation old Reginald Boots died.

By then I had become an Old Boy myself. Sometimes I sent in the odd cheque. I gave a medical lecture at Homecoming. I don't know if my talk was that riveting - I rambled on a touch and lost my place. I even yawned a couple of times.

The medical students looked like my children.

At least they were polite and soft-spoken.

Time is the greatest teacher, they say. Time teaches patience and humility. Time shows us more of ourselves as we grow. Those years at Medical House glow in reflection, the struggles, the camaraderie - I even seem to remember myself as lighthearted and carefree.

I have been to two Homecomings, and the last time I dropped by at Medical House and looked for my picture on the wall. After some searching I found a photo of a young man with long unruly hair who faintly resembled me. He appeared bewildered and rather naive.

Could I really have been that lost?

When I walked outside I noticed the Medical House roof was lopsided, the lawn could have used some raking and cleaning, and the windows needed fresh paint.

The odd thing was that everything seemed the same as it once had been.

The only difference was that there were Old Girls now.

Ronald Ruskin is a Staff Psychiatrist, Mount Sinai Hospital, Toronto, Ont 